\title{
Response to Windahl et al.
}

W e have read the article by Windahl et al. (1) with interest. While we agree with the conclusion that estren may not be a suitable clinical candidate for the treatment of postmenopausal osteoporosis due to effects on reproductive tissues that we did not observe (2), we strongly disagree with the interpretation of the evidence.

Postmenopausal osteoporosis is a disease of late adulthood in which bone loss occurs after peak bone mass has been established. Swiss-Webster and C57BL/6 mice do not reach peak bone mass until the age of 5 to 6 months (3). Accordingly, we (2) assessed the suitability of estren using 6- to 8-month-old animals and consider the use of 3-monthold mice inappropriate. In addition, by using 3-month-old C57BL/6 mice (20-25 g) as compared with 6- to 8-month-old SwissWebster mice (45-50 g), Windahl et al. have effectively doubled the original dose. Moreover, while $5 \mathrm{ng} / \mathrm{g} / \mathrm{d}$ of estradiol is needed to prevent loss of uterine weight in 3-monthold ovariectomized $\mathrm{C} 57 \mathrm{BL} / 6$ mice, an 8 -fold higher dose, $40 \mathrm{ng} / \mathrm{g} / \mathrm{d}$, is needed to prevent loss of uterine weight in 6-monthold C57BL/6 mice (4). Unlike Windahl et al., others have reported that, at the dose we had used, estren was ineffective in 10- to 12-weekold mice in a 3-day uterine bioassay (5) and that it exhibited only $16 \%$ of the activity of $17 \beta$-estradiol in 11-month-old mice (6). Hence, the difference between our 2 studies could simply be accounted for by the difference in the size and age of the animals.

While there is an 8-fold higher sensitivity of the uterus to estradiol in 3-versus 6 -month-old mice, estradiol at $5 \mathrm{ng} / \mathrm{g} / \mathrm{d}$ could prevent bone loss in both 3 - and 6-month-old C57BL/6 mice (4), indicating a differential sensitivity of uterus and bone to estrogen replacement in adulthood. Notably, a 2-year-long administration of very low-dose estradiol to postmenopausal women decreased bone turnover without endometrial changes (7). Previously, Galien et al. (8) used an isomer of estren to maintain bone mass but, similarly to the authors' new selective estrogen receptor modulator (SERM) PSK3471, it only "moderately increased" reproductive organ weight compared with that of controls, confirming our original finding that estren works on bone without affecting reproductive organs (2). This omission is disturbing. Worse, Supplemental Figure 3 shows that decreasing the dose of estren to $25 \mu \mathrm{g} / \mathrm{mouse} / \mathrm{d}$ significantly decreased the effect of the compound on seminal vesicle weight but did not diminish its beneficiary effect on bone volume. Yet the authors chose to interpret insignificant data - characterizing values as "somewhat decreased" - to buttress their conclusion that the effects of estren on bone and seminal vesicles cannot be separated.

The mice in the Windahl study had none of the expected cellular and biochemical changes that occur after loss of estrogens in mice and humans. Estradiol replacement increased rather than decreased osteoclast number, in opposition to multiple studies from the last 15 years. Also, despite the increase in osteoclast numbers, estrogen replacement increased trabecular bone volume as compared with that of the controls. Therefore, the authors concluded that estrogens (and PSK3471) are anabolic on bone. This is an erroneous and misleading conclusion, as it has been established that estrogens are anticatabolic/antiremodeling agents (9). Equally puzzling, PSK3471 had no effect on any parameter of bone turnover. That PSK3471 had the undesirable effect of stimulating uterine growth in both the myometrium and endometrium was completely ignored.

We and others have advanced the idea that the development of function-specific estrogen and androgen-receptor ligands could delineate the significance of nonclassical functions of these receptors. In the process, several biologic properties of these compounds not exhibited by the natural ligands have been discovered, including the ability to induce osteoblast differentiation by stimulating Wnt and BMP signaling in a kinase-dependent manner. In dismissing estren while promoting a SERM with similar unwanted effects, Windahl et al. not only have disposed of the scholarly obligation to offer an explanation for the significant discrepancies between their findings and those of many others but have also ignored their own data.

\section{Stavros C. Manolagas, Robert L. Jilka, Stavroula Kousteni, Teresita Bellido, Robert S. Weinstein, Charles A. O'Brien, Lilian Plotkin, and Li Han}

Division of Endocrinology \& Metabolism, Center for Osteoporosis \& Metabolic Bone Diseases, University of Arkansas for Medical Sciences and Central Arkansas Veterans Health Care System, Little Rock, Arkansas, USA.

Conflict of interest: S.C. Manolagas is a member of the Scientific Advisory Board, and S.C. Manolagas, R.L. Jilka, S. Kousteni, T. Bellido, R.S. Weinstein, and C.A. O'Brien own shares in Radius Health Inc.

Address correspondence to: Stavros C. Manolagas, 4301 W. Markham Street \#587, Little Rock, Arkansas 72205-7199, USA. Phone: (501) 686-5130; Fax: (501) 686-8148; E-mail: manolagasstavros@uams.edu.

J. Clin. Invest. 116:2834 (2006). doi:10.1172/ JCI30535.

1. Windahl, S.H., et al. 2006. Bone protection by estrens occurs through non-tissue-selective activation of the androgen receptor. J. Clin. Invest. 116:2500-2509. doi:10.1172/JCI28809.

2. Kousteni, S., et al. 2002. Reversal of bone loss in mice by nongenotropic signaling of sex steroids. Science. 298:843-846.

3. Weinstein, R.S., et al. 2004. The skeletal effects of glucocorticoid excess override those of orchidectomy in mice. Endocrinology. 145:1980-1987.

4. Modder, U.I., et al. 2004. Dose-response of estrogen on bone versus the uterus in ovariectomized mice. Eur. J. Endocrinol. 151:503-510.

5. Hewitt, S.C., Collins, J., Grissom, S., Hamilton, K., and Korach, K.S. 2006. Estren behaves as a weak estrogen rather than a nongenomic selective activator in the mouse uterus. Endocrinology. 147:2203-2214.

6. Moverare, S., et al. 2003. Estren is a selective estrogen receptor modulator with transcriptional activity. Mol. Pharmacol. 64:1428-1433.

7. Ettinger, B., et al. 2004. Effects of ultralow-dose transdermal estradiol on bone mineral density: a randomized clinical trial. Obstet. Gynecol. 104:443-451.

8. Galien, R., et al. 2004. Estrens protect bone against ovariectomy-induced bone loss in mice but fail to be selective on reproductive organs and/or breast cancer cell lines [abstract]. J. Bone Miner. Res. 19:S321.

9. Riggs, B.L., and Parfitt, A.M. 2005. Drugs used to treat osteoporosis: the critical need for a uniform nomenclature based on their action on bone remodeling. J. Bone Miner. Res. 20:177-184. 